\title{
From political militancy to becoming a teacher: revisited memories, intertwined (hi)stories*
}

\author{
Fátima Maria Leitão Araújo' \\ Marcus Aurelio Taborda de Oliveira"
}

\begin{abstract}
This article aims to analyze the life story of four female teachers, who were political militants against the Brazilian civil-military dictatorship in the 1960s and 1970s. Through their memories, we try to understand their school and academic trajectories, unveiling the main social institutional influences, ideas, and perspectives presented in their political formation process. Also, we aim to understand the definition of their roles as women, militants, and teachers, connecting the past and the present. We used oral history as empirical support, highlighting their life trajectories and observing the connection between family, public and private schools, Catholic Church, political parties, universities, and dictatorship agents. We conclude that political militancy during the teachers' youth period is an indelible aspect of their experiences, considering that they believed in youth transformation and their role in the changing society.
\end{abstract}

KEYWORDS

history of education; political militancy; teachers'lives; memories; education, and dictatorship.

'Universidade Estadual do Ceará, Fortaleza, CE, Brazil.

"Universidade Federal de Minas Gerais, Belo Horizonte, MG, Brazil.

*The article results of the project Evidences of the (self-)formation of workers in the press: affecting the senses, producing sensibilities (between the final decades of the 19th century and the initial ones of the 21st century). This is the post-doctoral research carried out between 2018 and 2019 by Fátima Maria Leitão Araújo at the Graduate Program in Education: Knowledge and Social Inclusion, at Universdade Federal de Minas Gerais, under the supervision of Marcus Aurelio Taborda de Oliveira. 


\title{
DA MILITÂNCIA POLITICA À CONSTITUIÇÃO DO SER PROFESSORA: MEMÓRIAS REVISITADAS, HISTÓRIAS ENTRELAÇADAS
}

\author{
RESUMO
}

Analisamos a história de vida de quatro educadoras, militantes no combate à ditadura civil-militar brasileira, nos anos de 1960-1970. Por meio de suas memórias buscamos entender suas trajetórias de formação, desvelando as principais influências no que concerne às instituições, ideias e perspectivas presentes em seus processos de formação política. Interessou-nos compreender a definição de suas posturas como mulheres, militantes e profissionais. Utilizando a história oral como suporte empírico, vislumbramos o entrelaçamento de vidas construídas com base em uma teia de sociabilidade na qual confluem instituições como a família, escolas públicas e privadas, Igreja católica, entidades e partidos políticos, universidade e agentes a serviço do estado ditatorial. Depreende-se por meio do estudo que a militância da juventude parece ter-se tornado marca indelével de suas experiências como professoras que creram na transformação da juventude e em seu papel na transformação da sociedade.

\section{PALAVRAS-CHAVE}

história da educação; militância política; vidas de professoras; memórias; educação e ditadura civil-militar.

\section{DE LA MILITANCIA POLITICA A LA CONSTITUCIÓN DE SER MAESTRA: MEMORIAS REVISADAS, HISTORIAS ENTRELAZADAS}

\section{RESUMEN}

El artículo tuvo como objetivo analizar la historia de vida de cuatro educadoras activistas contra la dictadura brasileña, en los años 1960-1970. Comprendemos sus trayectorias de formación escolar y académica, revelando las principales influencias con respecto a las instituciones sociales, ideas y perspectivas presentes en su formación política. Además, buscamos comprender la definición de sus posiciones como mujeres, activistas y profesionales, creando vínculos entre el pasado y el presente. La historia oral fue el soporte empírico, el estudio de sus trayectorias es el enfoque elegido. Visualizamos el entrelazamiento de vidas desde una red en la que convergen institución familiar, instituciones escolares públicas y privadas, iglesia católica, entidades y partidos políticos, universidad y agentes del estado dictatorial. Se deprende que el activismo juvenil parece haberse convertido en una marca indeleble de sus experiencias como maestras, educadoras que creían en la juventud y en su papel en la transformación de la sociedad.

\section{PALABRAS CLAVE}

historia de la educación; militancia política; vidas de profesoras; memorias; educación y dictadura militar. 


\section{INTRODUCTION}

In a period globally marked by the modernization and industrialization rhetoric, Brazilian society was also going through significant political, cultural, social, and economic transformations that took place between the 1950s and the 1960s, including the redefinition of its middle class. With the end of World War II, the country witnesses an optimistic and hopeful wave of modernization, also going through a rare moment of political stability, leading people to believe that democracy could be established in the country.

Even though life conditions in the cities decreased the distance between men and women, and new social practices glimpsed a new time, during the 1950s, the distinction between male and female roles was still clear. Thus, "being a mother, a wife, and a housewife was considered the natural destiny of women [...]. A woman who did not follow these pathways was going against nature"(Pinsk, 2018, p. 609). Therefore, women were responsible for protecting the home and, therefore, received an education that was compatible with their social role, which included supporting children's education and doing household chores to guarantee home stability and harmony, an heirloom from the late $19^{\text {th }}$ century. In the professional sphere, since the end of that century, women were part of the teaching force because, as teachers, they had a mission to educate children, the "future soldiers to serve the Nation", or foment the work ethos expected by a modernizing country (Lenharo, 1986, p. 40); without, however, giving up on the responsibilities of raising their own children.

In the 1960s, we can find other images of women, showing how they have transformed tradition by overcoming the barriers that restrained them in a position of creators of the future of the nation, turning themselves into active subjects in the fight against authoritarianism and social injustices. Several women's accomplishments in different countries have meant new horizons for them on the public scene, impacting Brazil. From being in charge of their sexuality, to having more of them in the job market, and to engaging in political fights, the role of women intensified a cultural renovation movement worldwide. The fights and conquests of the first feminist wave seemed to have definitely reached its universalization. The complexity of the role played by women in public life greatly surpassed its connection with formal education. However, that wave of changes shed on them new accomplishments connected with old practices and prejudices, overbearing their existence with the weight of gender inequality at work. If women aimed for autonomy and emancipation, the price to pay would be not redefining their place in public life only, but also continuing their work in the domestic sphere.

At that moment, women's life was permeated by a modern-traditional ambiguity, as women's participation in the job market, universities, and social life grew considerably, contributing to asserting their presence in the public scene. The traditional place reserved to women as beautiful and demure housewives gradually gave way to different types of participation, which were not restricted to the subordinate and supporting roles dictated by the Brazilian patriarchal tradition.

Though women have always played a prominent role in the cultural organization in Brazil, which was little studied by historic and educational researchers in 
the past, during the analyzed period, women also step into the limelight because of their political insertions, be it through the symbolic gesture of burning their bras, with emphasis on the concept of a free body in the form of bikinis and mini-skirts, the contraceptive pill, or through militancy in the power spheres heavily marked by men, such as political parties and the self-proclaimed revolutionary groups.

Based on the assumption that the women's role was crucial in the maelstrom of protests, claims, and transformations of sensibilities, we ask ourselves about the trajectories of women who became political militants, actively confronted the Brazilian regime and became teachers/educators simultaneously with and/or after having fought against the repression of the military government. We sought to reflect on their professional status, in an attempt to understand which societal and educational postures and concepts they assumed when becoming and being teachers.

Also, we address their experiences in times that are mixed and in times that revolve around their memories. After five decades, these educators talk about crucial moments of their lives, they talk about a past that is distant by the urgency of forgetfulness or present due to its painful character, but also due to the satisfaction felt when they realize their struggles were important for subsequent achievements. By recalling the facts, they see themselves in the past, in the many encounters made possible by their experiences; they reflect on the persons they have become and what still lingers from the past in their present lives. According to Walter Benjamin (1994, p. 198): "the experience that passes from one person to the other is a source to which all narrators resort. And, among written narratives, the best ones are those that differ the least from oral stories told by countless anonymous narrators".

\section{ON THE TRAILS OF MEMORY}

Understanding the personal and professional trajectories of "anonymous" people implies entering a world with no subjectivities of historic agents. Thus, the oral language, represented by fragments pinned by memory, was a methodological choice that allowed us to bring to light representations and realities that the written records could not transmit. Therefore, it is not a question of establishing a hierarchy of different types of sources, but recognizing the urgency of oral testimonies to build memory. A memory that is always missing something, that contains gaps, that is inescapably collective, but that has the marks of the individuals who experienced, body and soul, their way of establishing an "open dialogue with the world" (Thompsom, 1981). Memories interest us in their ethic dimension because the actions deriving from thinking, wanting, and judging define relevant permanent actions, continuous actions, and actions for understanding the past, in relation to the public dimension.

Oral history helps us to not only reach the universe of the forgotten, those that rarely appear on written documents, but also challenge the inherent judgment of traditional History and its myths (Thompson, 1998). Also, the "official memory", when intending to be hegemonic, neglected tensions and disputes that are reflected and founded on power relations. Part of such "official memory", which is currently 
returning under the guise of a "family woman", with a strong moralist and apolitical accent, proposes to silence the fights and neglects spaces where ordinary individuals express themselves politically, in this case, female teachers, imposing what should be remembered/recalled (Pollak, 1989).

Acknowledging that the use of narratives to understand the educational phenomena has been more common in recent years (Taborda de Oliveira, 2014), we emphasize the historic perspective. Thus, we deal with trajectories that could be understood from the procedures of oral history, intercrossed by other sources. Hence, we analyze the testimonies of militant women, unveiling memories that take them back to politically traumatizing times, allowing the delicate possibility of selecting what can be remembered, even when respecting the possibilities and the particular ways of remembering. In this sense, we try to understand a set of four experiences that reiterate the encounter between the individual and the collective in the threads of the history of militant female educators. Seen as a technique more than a method, we used oral history to understand the life trajectories of female students that would mark the Brazilian educational field with their peculiar political militancy. We entered the family spaces and the school education of these girls that became political militants during the 1964 civil-military dictatorship to get to know the most striking features of their trajectories. It seemed to be an important exercise to better understand the relationship between education, dictatorship, and the condition of women in Brazil.

The interviews took place between 2015 and 2018. We decided to conduct previously scheduled private interviews in a place chosen by the interviewee ${ }^{1}$. We located the interviewees based on information provided by researchers and former militants in the university field, as well as a previous research study carried out in associations and Comissões da Verdade $e^{2}$, in the states of Ceará and Minas Gerais, part of an exploratory research study. We created a general script for the interview, following the guidelines of Alberti (1990) and Thompson, (1992), previously used by Taborda de Oliveira (2018). We focused on information sets or descriptors:

- socialization;

- intellectual and professional training;

- participations;

- education and politics;

- a final word.

1 The interviews were conducted by professor Fátima Maria Leitão Araújo. She interviewed two educators from the state of Ceará: Maria Ruth B. Cavalcante, interviewed at the Centro de Desenvolvimento Humano - CDH, and Helena Serra Azul Monteiro, interviewed at Universidade Federal do Ceará - UFC, and two educators from the state of Minas Gerais: Maria Céres Pimenta Spínola Castro, at Universidade Federal de Minas Gerais - UFMG, and Efigênia Maria de Oliveira at her house in Cabo de Santo Agostinho, state of Pernambuco.

2 Truth Commissions (Comissões da Verdade) were committees held by the federal government to investigate human rights violations during the period between 1946-1988, but especially during the civil-military dictatorship (1964-1985) (Translation Note). 
The interviews were recorded and lasted an average of 100 to 125 minutes. From these general descriptors, the conversation was conducted towards producing memories based on enchaining recollections which, tough always socially embodied, are manifested through singular experiences. We were interested in information about their lives, their families, relationships and influences, their habits, professional training and studies, and their understanding of education and politics, which became analytical subcategories. However, aware of our objectives, we did not induce the interviewees to follow any specific direction. We simply let them recall the events that affected them more or less intensively. The material analyzed in this article is composed of the results of these exchanges of experiences. We did not have answers for many of the questions we had in mind. Nevertheless, there were some findings amidst an ocean of memories. Once consolidated, the interviews were transcribed and edited. Following the protocols of research ethics, after checking the content, all interviewees signed an informed consent form authorizing the use of their memories for research purposes ${ }^{3}$. If we were convinced of the importance to re-structure the past, we would know that this could never be done through quantitative perspectives that neglect the singularity of the experience.

Considering the ethic imperative of memory, we then understand that the testimonies of militant women against the Brazilian civil-military dictatorship can contribute to expanding a process that is still quite unusual among us: producing memory and redefining identities, individual and national ones. To understand the meanings and the importance that these educators assign to their social experiences, their professional training, and militancy, and how they reflected and still reflect their social and professional lives, we used Benjamin (1940) and Thompson (1981) reflections on experience and culture. Together with the analyses of the basis of teachers' professional practices, these reflections help us to state that the relationship between teachers and knowledge has not been reduced to a mechanical role of transmitting knowledge that has been previously established by "legitimation" agencies, such as universities, publishing companies, etc., even in authoritarian regimes, as stressed by Garrido (2020) and Kaufmann (2017), concerning the Chilean and Argentinean experiences, respectively.

An experience, which structures social life, is everything that moves individuals to constantly preserve or change themselves, as, throughout their existence, they are affected and marked by different situations that make them reflect and act a certain way, under the pressure of circumstances. In this constant exercise of living, they reflect on their dilemmas, positions in the world, and the actions of the world on them. When dealing with the life trajectories of our interviewees/ narrators, we are faced with experiences that are, at the same time, singular and peculiar to the social position of the speakers, but that also refer to a common culture (Williams, 2003) and political events, sometimes conservative, other times reactionaries, that mark the Brazilian political culture in the past 50 years. Events against which they resisted.

3 Research submitted to the Ethics Committee of Universidade Estadual do Ceara (UECE), approved by no. 93492218.0.0000.5534. 
Therefore, it is clear that ordinary people, herein represented by these militant-female-teachers, build their everyday lives, practices, and values; sometimes questioning, other times reinforcing traditions, that is, they live experiences that cannot be previously defined by any historic law. These experiences are not automatic reflexes of economic or political structures on the social consciousness. Listening to the women in this study implied recognizing that it is not possible to "understand any shape of social being that is independent of its concepts and organizing expectations" (Thompson, 1981). Therefore, we consider the militant educators to be protagonists of (hi)stories that are intertwined, despite the differences that set them apart not only geographic, but also the positions they hold in a social context permeated by inequalities. They are co-participants of a time full of ambiguities. A time not only of contestation, but also of fights that challenge deeply-rooted values which have denied the social role of women. We present and explore important nuances of their formative trajectories, their insertion on spaces of social and political militancy, and, following the paths through which they became teachers/ educators, we try to highlight their ideas of society and education, to which they still seem attached to even in their later years.

\section{THE INTERVIEWEES, THEIR FORMATIVE TRAJECTORIES, AND POLITICAL MILITANCY: INTERTWINED LIVES}

Brazil has gone through a period of redefining its middle class since the 1950s. With the end of World War II, the country witnessed, with optimism and hope, urban growth and industrialization, in addition to experiencing a rare moment of political stability, supporting the idea that democracy could, in fact, take roots in the country. Even though the life conditions in the city decreased the distance between men and women and the social practices gave glimpses of a new time, the distinctions between male and female roles were still clear. Thus "being a mother, wife, and housewife were considered the natural destiny of women [...]. The women who did not follow those paths were going against nature" (Pinsk, 2018, p. 609). It was up to women to protect their homes and, therefore, they should receive an education that was compatible with their social role: be responsible for the education of their children and do the household chores to guarantee the stability and harmony of the home, ideas that were already present at the end of the $19^{\text {th }}$ century. In the professional sphere, since the end of that century, women entered the educational field because, as teachers, they had the mission to educate children, future "soldiers at the service of the country" or foment the work ethos expected by a modernizing country (Lenharo, 1986, p.40), without, however, giving up on the responsibilities of raising their own children.

In the 1960s, we can find other images of women, showing how much they had transformed tradition by surmounting the frontiers that tied them to the role of 'creators of the future of the nation', becoming active subjects in the fight against authoritarianism and social injustices. Several women's accomplishments in different countries meant new horizons to women in the public scene. From 
being in charge of their sexuality, to having more of them in the job market, and to engaging in political fights, the role of women intensified a cultural renovation movement worldwide. The fights and conquests of the first feminist waves seemed to have reached their universalization. The complexity of the role played by women in public life extrapolated a great deal its connection with the universe of formal education. However, that wave of changes projected on them new achievements connected with old practices and prejudices, overloading their existence with the weight of gender inequality at work. If women searched autonomy and emancipation, the price to pay would be not only redefining their place in public life, but also continuing their work in the domestic sphere.

Four women narrate this (hi)story. They were born in the 1940s. In their youth, they participated in the effervescent movements connected with the progressive Catholic Church ${ }^{4}$ and student movements. Three of them belong to the urban middle classes, and one to the working class. From their testimonies, we can note that a keen critical awareness was present from an early age in their singular and distinct lives. Despite their different social backgrounds, family worldview, and the educational contexts of their schooling, they have similarities concerning issues related to their perspectives of society, which made them face the challenges imposed by the dictatorial times in Brazil.

The women interviewed subverted the "natural destiny" of their mothers in their youth. According to studies on the generational condition at the time, the changes triggered at that moment would affect the following generations. Cardoso (2005, p. 93) asserted that these generations would inherit the changes provoked by the social movements in those years, which resulted in the transformation of the image of women, "with feminism; sexual liberation; changes on family structure; glorification of youth as a way of life; flexibilization of hierarchies and authority; construction of new relationships between adults and youngsters, and adults and children". Therefore, an imaginary unity of a "generation from the 1960 " is created. Katya Braghini (2015) also helps us to understand the place of youth in the Brazilian culture at the time, especially in politics. Media outlets that supported an ideal model of a "traditional" youth strongly contrasted with the restless actions of youngsters who discovered themselves as protagonists. Part of

4 According to the final report of Comissão da Verdade em Minas Gerais - Volume IV (2018, p. 886): "At the time, the Church started a process of change that reflects the economic, political, and social transformations that took place in the country, more specifically in the South and Southeast regions: industrial growth, fast urbanization, and the strong presence in the populist politics of student, union, and rural movements. What best expresses the start of a new position of the Catholic Church was the incentive given to the different participation processes of laic people in Church actions. In this sense, we highlight the movement Catholic Action [Ação Católica] that assembled youth groups from different sectors of Brazilian society, under the following denominations: Rural Catholic Youth [Juventude Agrária Católica - JAC], Student Catholic Youth [Juventude Estudantil Católica - JEC], Independent Catholic Youth (Juventude Independente Católica - JIC), Working Catholic Youth (Juventude Operária CatólicaJOC), and University Catholic Youth (Juventude Universitária Católica - JUC)”. 
that youth thrived in high school and university student movements and would be strongly repressed by the authoritarian government. Among those young people, many of them were women.

We discover the most distinct marks of the trajectories of these girls, who would later become political militants during the civil-military dictatorship, within the families and the spaces of school education. It seemed to be a much-needed exercise to better understand the relationship between education, dictatorship, and the condition of women in Brazil. The interviews outlined herein took place between 2015 and 2018 and were individually held at a scheduled time, in a place chosen by the interviewee ${ }^{5}$. We located the interviewees through information provided by researchers and former militants in the university field, as well as a survey on associations and Comissões da Verdade, in the states of Ceará and Minas Gerais. We held semi-structured interviews with an average length of 100-125 minutes. Those were later transcribed and edited. Following the protocols of research ethics, all interviewees signed an informed consent form, authorizing the use of their memories in the research ${ }^{6}$.

\section{HELENA SERRA AZUL MONTEIRO ${ }^{7}$}

She was born in Fortaleza in 1947. She highlights the role of her paternal grandfather, an intellectual and professor who worked against Getúlio Vargas's dictatorship, as key to her formation. Her moment of greatest action against the military regime was at the Universidade Federal do Ceará, when she had contact with the group Popular Action $(A c ̧ \tilde{a} o \text { Popular }-A P)^{8}$ and worked intensely to fight for students' rights.

Her father and grandfather were fundamental in valuing and encouraging her professional choices and ideological stances. Following the family tradition, she studied at Colégio da Imaculada Conceição ${ }^{9}$. In 1964, she did her sophomore and

5 We interviewed two educators from the state of Ceará, Maria Ruth B. Cavalcante, interviewed in the $C D H$, and Helena Serra Azul Monteiro, interviewed at Universidade Federal do Ceará (UFC), and two educators from the state of Minas Gerais: Maria Céres Pimenta Spínola Castro, at Universidade Federal de Minas Gerais (UFMG), and Efigênia Maria de Oliveira at her house in Cabo de Santo Agostinho, state of Pernambuco.

6 Research submitted to the Ethics Committee of Universidade Estadual do Ceara (UECE), approved by report no. 93492218.0.0000.5534.

7 Interview carried out on April 5 ${ }^{\text {th }}, 2017$, at Universidade Federal do Ceará, in Fortaleza.

8 National political organization founded during a congress promoted by JUC in Belo Horizonte, between May $31^{\text {st }}$ and June $3^{\text {rd }}, 1962$. It was mainly formed by members of JUC and Juventude Estudantil Católica (JEC). Its objective was to form leaders that could "participate in a radical transformation of the Brazilian structure in its passage from capitalism to socialism."

9 Colégio da Imaculada Conceição, from the Order of Vicent de Paul, was founded in 1865, aiming to educate and shelter orphan girls. It became a reference for the education of upper-class children in Ceará. Many of them were educated there, including important names in the history of the state, such as writer Rachel de Queiroz. 
junior year, Scientific studies, at Colégio São João ${ }^{10}$, where she started her political actions in the student council. Her senior year was at Colégio Castelo, a school that, according to her, welcomed the teachers connected with Brazilian Communist Party (Partido Comunista Brasileiro - PCB) who were expelled by the university. These teachers brought to the classroom a discourse against the military regime. It was there that she had her first contact with Student Catholic Youth (Juventude Estudantil Católica-JEC) and AP. When graduating from high school, she joined Medical School. A professional choice that conflicted with the traditional view of women's role in the Catholic society of Fortaleza at the time.

During her time at $A P$, she studied the works of Marx, Mao Tsé Tung, and Lenin. With the strengthening of dictatorship in 1968, she was persecuted by her political actions and started to live a clandestine life. In these circumstances, she moved to Pernambuco, where Ligas Camponesas ${ }^{11}$ was based, and lived in Recife. Regarding her political engagement, Helena highlights:

Ação Popular was an organization that fought against dictatorship, but not only against dictatorship. It also had the perspective of a socialist society. So, we started to discuss the revolutionary model, which was the Maoist one [...]. We studied the classics deeply: Marx, Lenin, and much of Mao Tsé Tung. We thought Brazil had a model close to China, the number of people and everything else. AP was really Maoist and, on top of that, it even established a tactic and a strategy of fight within the student movement. But this also took place simultaneously with the repression. So, for example, I participated in 1967 and $1968 \ldots$ And in 1968 , there is the AI- $5^{12}$ [...]. Up to 1968 , we were only in the student movement and, sure, in an organization that had another perspective.

Thus, due to her action in Recife, she was arrested in 1969, while being two months pregnant. After two years, with the help of a priest, she was released and

10 A private school founded in Fortaleza in 1930 and purchased in the 1970s by a large private educational company of Ceará.

11 The first Peasant Leagues (Ligas Camponesas) appeared in 1945, after the end of President Getúlio Vargas' term of office (1930-1945). The first Ligas Camponesas, under the direction of the recently legalized $P C B$, had as one of its objectives to discuss the agrarian situation and the relationships established in the country in a period when powerful landowners had a great influence in national politics. It was one of the most important movements in Brazil in favor of the land reform and the improvement of life conditions in rural areas. The movie Cabra marcado para morrer (Twenty years later) by Eduardo Coutinho, about that experience, became iconic. The movie of 1962 portrays the assassination of João Pedro Teixeira, leader of Liga Camponesa de Sapé, in the state of Paraíba, ordered by powerful landowners.

12 Ato Institucional n. 5 (Institutional Act no. 5) was decreed on December $13^{\text {th }}, 1968$. It empowered the president to close the National Congress and the State Legislative Assemblies, intervene in states and cities, censor the press and art forms, forbade non-authorized political meetings, suspend habeas corpus for politically-motivated crimes, and allowed the president to fire any public servant, including elected ones. (Translation Note). 
returned to Fortaleza. In 1973, she graduated but, during her professional career, she had problems finding a job. Her political action did not disappear when she graduated. Later, she started to work on $P C d o B$, and took part in the movement Diretas Já. ${ }^{\prime 3}$. She was a member of Comissão Nacional da Verdade of Ceará, which investigated human rights violations committed by government agents during the dictatorship. She became a professor at the Medical School of UFC, but is currently retired, and continues to be a researcher and professor at the Graduate School in Pharmacology at the same university. She is a widow of an important militant of Communist Party of Brazil (Partido Comunista do Brasil - PCdoB), known as Chico Passeata (roughly translated as Marching Chico), and a mother of two children.

\section{MARIA RUTH BARRETO CAVALCANTE ${ }^{14}$}

She was born in 1944, in the city of Pedra Branca, the countryside of Ceará. From an influential family of inland Ceará, Ruth highlights that "she was born within a collective" due to the great number of people in her family. She tells us that: "I'm from a typical Northeast, Ceará family [...] my father had seven children in his first marriage. Then he married my mom and had 13 more. So, we are a 20 -people family". In this sense, according to her, the dynamic and experience on her father's farm, allowed her "the opportunity of getting in touch with many social groups, setting her "social essence", giving her, from an early age, a "collective spirit", and a communal experience.

The beginning of her school life was in her hometown in the backlands of Ceará. Later, in Fortaleza, she studied at Colégio da Imaculada Conceição. Due to the strict rules of the school, she was expelled and then attended Colégio Santa Cecilia, also part of a network of private Catholic schools. She studied there for a short time as her rebel posture resulted in her being expelled again. She then studied at Colégio Santa Isabel, where she started to have closer contact with political experiences through JEC. She played a prominent role in the student council, and her political and educational trajectory developed through Movimento de Educação de Base (MEB - Grassroots Educational Movement). In this movement, she played different roles, she was a teacher, a supervisor, and a coordinator. Simultaneously with her participation at MEB, she enrolled in the Pedagogy Program at Universidade Federal do Ceará (UFC), in 1966.

At the university, she had a stronger political militancy against the dictatorial regime. She started working at $A c ̧ \tilde{a} o$ Popular (AP) and was a leader at DCE ( $D i-$

13 Diretas Já was a civil movement held between 1983 and 1984, demanding direct presidential elections in Brazil. (Translation Note).

14 Interview held on November $13^{\text {th }}, 2015$, at the $C D H$, in Fortaleza, state of Ceará. Other contacts were made in 2016 and 2017 to include more information about her professional experiences. Some of her works were given by her to the research, as well as newspaper clippings of her interviews. 
retório Central de Estudantes - Core Student Council) ${ }^{15}$, in 1968. Her work was one of the reasons for her contact with political parties, such as PCdoB, that followed the Maoist influences of rural guerrilla. Her main theoretical references at the time were Dominican Louis-Joseph Lebret ${ }^{16}$ and Brazilian Paulo Freire. She was the first woman to head DCE and the only one at Congresso de Ibiuna, in 1968, against whom preventive detention was ordered. According to her, "that was a very tense moment, and the detention of hundreds of student leaders strongly reverberated in the country". Ruth was the first woman to be arrested at Hospital Militar de Fortaleza - the fact that there was no women's prison for political prisoners helps us to understand how novel this was in the Brazilian political culture. It was from this hospital that she escaped, in one of the most commented prison breaks in the recent history of Ceará, if not Brazil. She pretended to be her sister and fled during visiting hours, deceiving the guards of a whole station. In exile, she lived in Chile and Germany with her partner, also a militant, João de Paula Monteiro Ferreira, a Medical student at the time. Her oldest child, Mariana, was born in Germany, during her exile, with Down syndrome, changing her story as a mother. Her daughter inspired the $\mathrm{CDH}^{17}$, created and chaired by Ruth when she returned to Ceará after the amnesty. Ruth married a second time and had two other children.

\section{EFIGÊNIA MARIA DE OLIVEIRA ${ }^{18}$}

Efigênia de Oliveira was born on August 31 ${ }^{\text {st }}$ 1944, in Brumadinho - state of Minas Gerais, to a family of nine children, six boys and three girls. Her parents were José Pinto de Oliveira, a railway worker, and Carmelina Paula de Oliveira, a

15 To Rodrigo Patto Sá Mota (2014, p. 24): “The hegemonic anticommunist representations among the winners of 1964 distorted the communist objective and, above all, its real capacity to influence events". However, though distorted, such arguments were not absurd, "as communists had an important influence among student leaders" [...] in the student movement, the strongest group was connected to the Catholic left, the Ação Popular (AP), that invariably had the presidency of UNE (Idem).

16 French priest and economist Lebret was an important name of the Catholic Church history in the second half of the $20^{\text {th }}$ century. His name gained projection due to the alert he gave the Church on global development themes. He had an important participation on the Second Vatican Council, between 1962 and 1965, and was nominated an expert by recommendation of Dom Helder Câmara on issues of social development. It is worth noting that Helder Câmara was an active counselor of Conselho Federal de Educação (Federal Education Council) in the 1960s.

17 The $\mathrm{CDH}$ is an institution that cares for children, youngsters, adults, and the elders. Its transdisciplinary team is composed of experts on human development processes, in their psychological, physical, intellectual, spiritual, and sociocultural dimensions, with emphasis on an emotional reeducation for life, expansion of consciousness, and moral and ethical development. It was founded in 1981 by Edna Machado de Oliveira, João de Paula Monteiro Ferreira, Maria de Fátima Pereira Diógenes, and Maria Ruth Barreto Cavalcante.

18 Interview held at her house in Cabo de Santo Agostinho, in the state of Pernambuco, on December $4^{\text {th }}, 2017$. 
housewife. Her mother always encouraged her to study. From an early age, Efigênia was interested in teaching, which led her to take extra exams, while still in the $4^{\text {th }}$ grade, to be admitted into the Escola Normal Helena Antipoff, in Ibirité, Minas Gerais, to become a teacher.

She stayed in that city for some years where she started the work that would mark her entire life: educating youngsters and adults, though she had also taught children in multilevel classes in rural areas. As her family was large and their town did not offer work possibilities for all, they moved to the industrial city of Contagem, in the metropolitan region of the state capital, Belo Horizonte. There, her siblings worked in factories. Efigênia was also a factory worker, but continued to teach at night, after her shift.

She started her political militancy while teaching youngsters and adults how to read and write, as well as working in the factory. In Contagem, Efigênia started to have a prominent role as a union leader, participating in the Greve de Contagem $^{19}$, in 1968, the year president General Costa e Silva decreed AI-5, when the Brazilian dictatorship got even harder. Despite arresting and persecuting innumerous militants, amongst them Efigênia, the military and the businessmen had to give in and grant a 10\% salary increase to all workers, thus breaking for the first time the no-salary increase policy at the time. It was in this scenario that her political persecution started. She says "We stopped after a metalworkers' strike in Belo Horizonte ...the whole city stopped, all metal factories, then I was fired, persecuted, I kept running away from place to place, then one day I was arrested". Arrested in 1976, Efigênia was only freed in 1979. In prison, Efigênia started talking with the other female political prisoners, who were doctors, lawyers, students, who had in common the militancy against that regime that stripped away freedom, popular participation, the possibility of wealth distribution, and democracy, that was still under construction in the previous decade. According to her, the period she was arrested was, despite everything, a very productive one as they had access to books. Then, she took advantage of the time in prison and, together with the other inmates, organized a group. In her memory, the readings and discussions of the group helped ease the horror and the atrocities of prison. In 1979, with the Amnesty Law, she left prison and returned to Contagem, where she met her current husband, from the state of Maranhão, who was also a persecuted and imprisoned militant.

The painful marks of her time in prison and the persecutions could be seen in her emotions while she was talking: "We leave the prison, but the prison doesn't leave us!". Her left-wing militancy as a young woman seems to be significant and influenced her professionally. After the dictatorship, she continued to work as a teacher, working in Young and Adult Education, now in the rural area of Pernam-

19 Greve de Contagem (Contagem Strike) in 1968 is known in the Union History of Brazil as the "short year of all wishes", according to Daniel Aarão Reis Filho. For this historian, "Osasco and Contagem became magical words, announcing apocalyptic confrontations". Some student assemblies excitedly heard workers' leaders asking for support. They promoted bonus sales, handed in leaflets in factories and bus stops, and held solidarity demonstrations" (Reis Filho, 1998, p. 4). 
buco. The militancy can also be seen in her political actions in the government of Miguel Arraes, when trying to reestablish the rural leagues in the state. She currently lives in her country house, in the city of Cabo de Santo Agostinho, with her partner and three children.

\section{MARIA CÉRES PIMENTA SPÍNOLA CASTRO20}

The fifth daughter in a family of nine children, six women and three men, she spent her childhood in the towns of Capelinha and Bocaiúva, both in the state of Minas Gerais. Her father was a prosecutor and a judge in Bocaiúva, Montes Claros, and Belo Horizonte. Her mother was an elementary school teacher in Bocaiúva and Montes Claros. From an early age, the children were encouraged to study and take a course that allowed them to work. In the interviewee's opinion, at that time "judges didn't earn as much as they do today". In this sense, school education was needed to guarantee a less difficult life for the family. When she was 13 , she started her militancy on the student movement, trying to create a student council at Colégio Imaculada Conceiçãa ${ }^{21}$. In 1964, at the age of 15, during her first year in the Teacher Training course, she would feel the first impact of the military coup. At that time, together with an older sister, she started her contact with $J E C$. The organization was divided into JECM, the Men's Catholic Student Youth, and the JECF, the Women's Catholic Student Youth. The priest who guided both groups was persecuted and removed from the school, and that really impacted them.

When graduating from the Teacher Training course, her sister moved to Belo Horizonte where she started an undergraduate program in Psychology. Maria Ceres then started a Higher Education degree, but she did not want to be a teacher. She claimed that she did not accept that women's professional destiny had to be restricted to teaching. In her family, almost every woman had become a teacher, but she wanted to follow another path in which she could work with social issues. A nun with whom she talked suggested trying the Social Services program. She then took the university entrance exam and was admitted at Universidade Católica de Minas Gerais. Her father said that he would 'give' her daughters the Teaching diploma and, after that, he would help only if it were possible, otherwise, they would have to teach to support themselves. Because of that, in February 1967, when she was 17 years old, she started to teach at Grupo Escolar Maria Salomé Pena, in São Bernardo neighborhood, in Belo Horizonte. At the end of the same year, she joined the state educational system through a public exam.

Being employed, Maria Ceres could take the undergraduate program in Social Services and pay her expenses. During the day she would study and at night

20 Interview held on May $3^{\text {rd }}, 2018$, at the Pampulha campus of UFMG, in Belo Horizonte.

21 A school from the congregation Filhas de Jesus started to work on September $16^{\text {th }}$, 1916 in a chalet in the city of Montes Claros, state of Minas Gerais. Since the beginning, it offered kindergarten, high school, and embroidery private classes. Colégio Imaculada Conceição also offered special courses of solfeggio, singing, French, Spanish, drawing, painting, flower making, and sewing. 
she would teach an adult class. In that period, she joined $A P$. After graduating in Social Services, she was hired as a social assistant at Hospital Maria Amélia Lins, formerly known as Pronto Socorro Policial and today known as Hospital João XXIII. She was arrested at the end of 1971, in an operation known as Operação Soraia. After some days in prison, she was released and got back to her job, having to face a lawsuit in the Military Justice System, in Juiz de Fora. She was acquitted in the basic court and the lawsuit followed to the Superior Military Court.

At 23 years old, she married a journalist and militant. At the year of her marriage, 1973, she took on the position of social assistant at Companbia de Saneamento de Minas Gerais-COPASA, but had to step out soon after that because she was facing a new criminal procedure, now from the state of São Paulo, when her preventive detention was decreed for crimes related to National Security. This lawsuit was forwarded to the Superior Military Court, adding to the previous one. She was judged and acquitted only 10 years later. Though she escaped prison, she faced difficulties and prejudice because of the long time it took for the lawsuit to be closed.

She became a professor at Universidade Federal de Minas Gerais (UFMG), in the Department of Social Communication. She pursued her Master's in Education at UFMG (1982) and a Doctorate in Social Sciences at UNICAMP (1994). In 1997, she was appointed Secretary of Education of Belo Horizonte. Besides that, she was the Director of Social Communication at UFMG, Sub secretary of Human Rights in the Secretariat of Social Development of Minas Gerais, and Adjunct Secretary of the Secretariat of Education of Minas Gerais. She was appointed by the State Government to take part in Comissão da Verdade in Minas Gerais, from 2013 to 2018.

\section{FROM THE MAELSTROM OF DARK TIMES TO BECOMING A TEACHER/EDUCATOR}

Talking about women in their political actions during the Military Dictatorship is looking into a universe of "double transgression", a term used by Ana Maria Colling in her work entitled As mulheres e a ditadura militar no Brasil (Women and the Military Dictatorship in Brazil) (2004). The militants' behaviors inflicted the codes of conduct at the time, considering that the main role of women was related to the family and the home, not to the political and public spheres of society. Therefore, the universe of women and political actions during dictatorship alludes to the transgression of values associated with women and an opposition to the repressive government established in Brazil, mixing elements of political repression and perspectives of "moralization" of customs.

Four women with intertwined trajectories and lives that express a time of intense changes and challenges. Like millions of other Latin American women, who also experienced dictatorial times, they started to understand the close relationship between their lives and the political regime. They became political activists, left the place that had been designated to them, going beyond the walls that limited 
women's action in a society still marked by sexism and patriarchal political despotism. They became militants, honoring the skirts they wore, shaking to the beat of a nonconformist choreography.

By alluding to "skirts", we refer to the characteristic uniform worn in girls' schools, especially in the ones offering Teacher Training, that is still present in the imaginary of society. By opposing themselves to the images of femininity found in the stories shared in this work, they faced a moment of transgression of the norms, concepts, and social conventions that imprisoned them into an ideal of woman. They experienced miniskirts, liberation, the bra-burning movement, and the possibility of wearing pants, which was, until that time, restricted to men. Besides that, some of them adopted the "militant's universal model" at a time of "formation", which "included the de-sexualization of the militant, who should stop being a woman and become a militant only - a universal male subject” (Rosa, 2013, p. 43).

In the testimonies, we could see a strong Catholic influence in the formative trajectories of these women. The moral and ethical principles of Catholicism were the fundamental bases on which their political militance was built. A religious basis that started in the family, grew in the school, and solidified later in life, when they were more aware of social, economic, and political inequalities in Latin America and Brazil. The awakening to social problems was intensified after the contact with Christian socialism, in which they supported their more incisive actions within the student movement. At that moment, Catholic young people acted more independently from the clerical institution, having more autonomy and taking political positions that were recriminated and persecuted by more traditional segments of the Church ${ }^{22}$.

Catholic youth movements, especially the Juventude Universitária Católica (JUC), intended to end hunger, misery, and social injustice, aiming at national prosperity and dignity for all. The action of its militants was gradually intensified and, in 1960, a few years before the military coup, this student organization gained prominence due to the support offered by political parties, leading to, in a near future, the work of their activists in left-wing political parties.

Still in 1960, fighting for human rights, the JUC movement started to affirm itself beyond the Catholic guidelines, suffering political repression. This

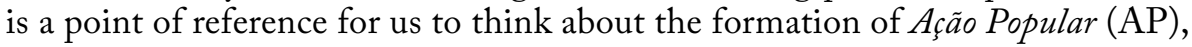
a movement in which most militants joined. Therefore, the Catholic movements,

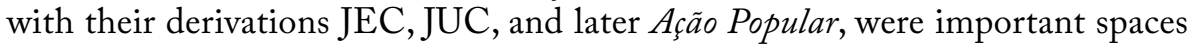
of political and ideological formation for these girls and young women. In this context full of changes, ruptures, and contradictions, we also highlight the strong presence of Paulo Freire's pedagogy materialized in the Movimento de Educação de Base (MEB) (Grassroots Educational Movement). In a mixture of Catholic

22 It is worth remembering that the Catholic Church was one of the institutions that supported the 1964 Coup and the dictatorship during its first years. Only after recognizing the violence and the persecution nature of the regime, some important names of the Catholic structure started to fight its authoritarianism and support those persecuted by the dictatorship. 
ideas, Freirean pedagogy, and revolutionary political influences, as Maoism and Leninism, we see the hybridism that moved part of the youth militancy in that period. Schools, despite their traditionalism and strict principles of women's formation, were a favorable locus for the student movements because of the increased authoritarianism during the military regime, as shown by historiography (Germano, 2011; Braghini, 2015).

Out of the four interviewees, three (Helena, Ruth, and Maria Ceres) mentioned their work at JUC, which would lead them to have more expressive participation in the student movement, giving them a prominent space as leaders in the academic movement. With time, their actions within the Catholic youth movement gained more significant proportions in their student militancy, assuming political action responsibilities as part of their commitment to youth and, soon later, the Brazilian society. These movements boosted the political militancy of many young people who joined educational institutions during and after the civil-military coup of 1964. Not surprisingly, student movements were one of the groups most persecuted by the repression authorities. Great media outlets fought for the hearts and minds of these youngsters, as in the case of Revista Realidade, studied by Braghini (2014).

Since the beginning, Ruth and Efigênia worked as teachers in Young and Adult Education (YAE). In Ruth's case, her experience with Paulo Freire pedagogy was decisive, not only to her militancy but also as a student of Pedagogy at UFC throughout her trajectory of life. In the case of Efigênia, her experience with teaching children and rural workers to read and write, together with her work at the factory, brought her in contact with the social movements, especially unions, thus starting her militancy in union movements and neighborhood movements. Helena Antipoff school was a key locus of her professional and human formation, as can be seen in this excerpt "At the time, I had learned a bit about Paulo Freire at Helena Antipoff [...] And we learned a lot from her, a lot...many workers learned how to read and write with me... I was young... seventeen, eighteen years old, that was when I started".

While Ruth and Efigênia started teaching from an early age, following what was expected by their training at Teacher Training schools, Helena and Maria Ceres never wanted to become teachers. Helena had always aimed to be a doctor and had her father's support. She, the eldest of three daughters, considered him to be a "man ahead of his time". Maria Ceres pursued another professional training. However, for having to support herself financially in Belo Horizonte, she decided to become a teacher at Minas Gerais public educational system. In the mid-70s, Maria Ceres became a professor at the Communication School of UFMG. In Helena's case, after the challenges faced as a former political prisoner and exile, she became a Higher Education professor. The two women who were "unlikely to be teachers" ended up having prominent careers as academic writers and researchers.

Regarding their teaching experiences, what do these four women tell us about the relationship between school education, social experiences, political militancy, and professional choice? What political and educational concepts guided and still guide their teaching practices? Would it be possible to establish the contributions 
and influences of their political militancy experiences in their educational concepts and practices?

Helena Serra Azul's professional trajectory in teaching is peculiar. After graduating from Medical School, she faced several problems in the job market. According to her, after she graduated, there was a selection process for a temporary teaching position at Universidade Federal do Ceará (UFC). However, she was not able to enroll because she had to submit an "ideological certificate", which was impossible for her due to her past as a former political prisoner. She took a specialization course, medical residence, and a doctorate in Medical Sciences at Unicamp. To Helena, it was her identification with the academic area that led her to teaching. Research and teaching are two passions that move her life until the present day, even after being retired, as she still contributes to the graduate school. After her first teaching experience at Pontifícia Universidade Católica (PUC) São Paulo, she took a public exam in Clinical Pharmacology and was hired by UFC in 1991. About being a teacher, she says:

I started in 1991 and, since then, I got involved with research. I am now a $\mathrm{CNPq}$ researcher. I advise master's dissertation and doctoral thesis students. I usually joke by telling people I have scientific and technical training, but I also have a political position, I have a side [...] Even as a researcher, there isn't anything that is not political, everything is political. Even science is within a context. So, for example, if I study pharmaceutical drugs, this has to benefit science development, but you don't see science for the sake of science. It is for humanity, you know? For people $[. .$.

In her testimony, the teacher and researcher made it clear that she expresses her political positions to her students. Besides that, in her classes, despite following scientific contents rigorously, her political perspective, which is concerned with health and society, is a key element in training future physicians.

In the case of Ruth Cavalcante's trajectory, she guides us to the story of a young woman who started teaching right after graduating from the Teacher Training school. Her Portuguese teacher, Ivone Garcia, that worked at Movimento de Educação de Base (MEB), recommended Ruth as the teacher who could substitute her. To Ruth, the invitation allowed her to strengthen her identity as an educator. Her experience at MEB and her contact with the Movimento de Educação Popular were extremely significant for her life, as pointed out in her memories.

It was a highly qualified team; I was the youngest and was chosen to be a teacher who would teach through the radio [...] We taught how to read and write using the Paulo Freire method. This method taught people to read and write in 45 hours, with in-person classes, which is about 3 months; through the radio, we taught students for 6 months. It was a success that in 6 months we could teach rural workers, who had never gone to school, how to read and write. 
Ruth highlights the importance of MEB, a nationally organized initiative, which was a true school to her. She is proud of her time in the movement, when she worked as a teacher through the radio, supervisor, and coordinator, in Fortaleza. Due to her immersion in these activities, she had no desire to go to university. But after three years in the movement, she realized the importance of having a Higher Education Degree. Then, together with her work at MEB, she started to study Pedagogy at the Education School of UFC. Her militancy was intensified both as a university student and as a Freirean educator. At the university, her main fight was against the University Reform and, mainly, the Ministério da Educação e Cultura (Brasil) - United States Agency for Internacional Development (MEC-USAID) agreements. With the intensification of the military repression after AI-5, Ruth's life would take a different direction. She was in her junior year at university and her commitment to a liberating education led her to offer courses on the method at the School of Education, open to everyone interested in developing the Paulo Freire method. In her words: AI-5 was the coup within the coup that forbade Paulo Freire [...]. So, I ignored the party, we weren't even supposed to sleep at home, let alone attend university. [...] But I had made a commitment. At that time I didn't feel like a student, I felt like an Education professional that was teaching a course.

When she went to the university to tell her class that she could no longer continue the course, she was ambushed by the police and arrested. After her escape, she lived clandestinely with her partner, passing by Pernambuco and São Paulo, disguised as rural workers. When the situation became unbearable, they exiled themselves in Chile and, later, in Germany. After establishing themselves in Europe, she started an undergraduate program in Psychopedagogy. In Germany, her daughter Mariana was born with Down Syndrome and this inspired her to search for more information and new paths for the cognitive and psychosocial development of her child. Freire's pedagogy, which has always guided her educational concepts and practices, was mixed with the assumptions of Biocentric Education. About this perspective, she explains: "We have to constantly ask ourselves: what am I doing now, does it generate life? Life has to be seen from the perspective of those that most need their lives to have potential, those who are oppressed, rejected, handicapped, everyone who is socially excluded". This is how Ruth defines herself as an educator:

I define myself as someone who is deeply inserted in my time. I was there at that time, in that shape. Now, I am inserted in this time of mine, with my age, my experience, everything I have. So, in fact, I live where I am. I think about Paulo Freire when he says "we have to form beings in the world and beings of the world". I feel like a being in the world, as part of it all, and a being of the world that transforms it all. So, in the place I am, that is what I search for. But why do I search it for? Only for my personal satisfaction? For my individual joy? No way. I have a strong commitment to the collective and I think that every social space is a space for education, wherever we are, not only in the classroom. Every place can be a place that creates learning and development for people. 
Like Ruth Cavalcante, Efigênia Maria de Oliveira's trajectory was always identified with teaching. Confirming a common memory of many teachers, she claimed that from an early age she "dreamed" of becoming a teacher. After graduating from the Teacher Training high school in Ibirité, she moved to Contagem, where she focused on Adult Education: "I started to teach adults how to read and write because, at that time, many workers were illiterate, they could barely write their names, I mean, they drew their names, you know? They didn't even know what they were writing”. Efigênia retells her life, permeated with struggles and difficulties, but full of utopia and willingness to change society. She started to teach during the last year of João Goulart's government, engaged in a factory union movement, and with the commitment to teach rural workers at nighttime. Thus, she would face persecution after the 1964 coup. In her testimony, she highlights:

AI-5 was a total disaster. At that time, when all the leaders had already been arrested, they started to persecute the base, because there were undercover agents everywhere, everywhere we worked (...) The good thing was that, at that moment, we had a lot of support from the progressive Church. Because the church also worked with the so-called Grassroots Community and we joined those communities...to help the Church, to keep doing the social work we did and, even, in the role of teachers... It was when we could really multiply the number of teachers to place them in all those outskirt neighborhoods, the favelas and all. Through literacy...you are not only teaching an adult to read and write because they need to and it was important to them. You are also politicizing them, raising awareness...

Efigênia stresses her mother's role in her life and that of her siblings. Besides the importance she gave to studying, she supported her children in the causes they chose and their political militancy (besides Efigência, a sister and some of her brothers were also involved in union movements). She describes her mother as follows:

"She was a countrywoman, from the inland, but an extremely sensitive person...She supported us a lot. My father has never done this. He was the son of a Spanish man, who fled to Brazil escaping the Spanish Civil War, so, he was horrified, horrified!"

We can see how much the militancy experience is marked in Efigênia's speech and expressions. When referring to her three years in prison, she recalled many times that the group built with other inmates was one of the ways to survive and keep strong in jail. According to her, there was a great exchange of knowledge and a safe sharing of experiences. She asserts: "So, we also had to use this time to study. We believed that one day we would make a Revolution and this country would be different... We dreamed about that. We dreamed about that, that one day 
we would leave prison and keep going”. Regarding her teaching experiences, she also highlighted the influence of the Freirean pedagogy ${ }^{23}$.

A woman and a militant, she insists that she prefers to be called an educator and not a teacher. To her, being an educator has a broader and more complete dimension of educating and reinventing oneself, of learning while teaching, in an "endless process of building the being". Regarding her legacy as an educator, we can see an emphasis on young and adult education, a constant in her militancy. Her work started in Minas Gerais and continued in Pernambuco, when she arrived in the early 1980s. To her, education is a powerful weapon to free the oppressed people, especially those in the rural area, where she mostly worked.

Finally, differently from Efigênia, Maria Ceres Pimenta, as we have previously stated, never wanted to become a teacher. She wanted to distance herself from a profession that was destined for the women in her generation, also because it was an imposition of her family and the society at the time. The expansion of the middle-class at the time allowed not only a greater presence in the job market, but also an expansion of Brazilian Higher education. This meant, for some women, the possibility of not passively following the tradition. While still a student in the undergraduate program of Social Services at PUC Minas Gerais, she was a teacher only as a means of survival. Her university career started in 1975, when she was invited to be part of a group that would discuss the creation of the Social Services program at UFMG. She highlighted: "I had a criminal record, but he [the dean $]^{24}$ authorized it. They told me he looked at me and later said "It makes no sense that this young woman is considered to be that dangerous" (laughs). According to her, due to political issues, the Social Services program was not created.Then, she became a professor in the Department of Social Communication.

Though never wishing to be a teacher, Maria Ceres has built a successful professional trajectory in teaching and education. As the Secretary of Education of Belo Horizonte, in the late 1990s and 2000s, she led actions that she defined as "pioneer" in Brazilian Education, such as the creation of Bolsa Escola and the 9-year elementary/ middle school. During her interview, we can see how the memories of her professional trajectory in the areas of teaching, researching, and management make her happy for everything she has done and conquered. This is one of the dilemmas of memory: how it can be produced to ease the dilemmas of our past and present choices. However, memories are also made of progress, hesitations, omissions, choices, gaps, excesses.

23 This aspect, which will not be further addressed here, deserves to be studied more deeply. At a time when educational technicism was the norm and the debate on alternative pedagogies or the ideological and/or emancipatory role of education was still shy, the legacy of Paulo Freire seems to have become a guide, if not the only guide, to those who thought about a more critical education. On top of that, there is the aspect of nationalism that also impacts many left-wing movements. Some groups clearly wanted a revolution and the defeat of capitalism. Others, more reformists, moved around an agenda that claimed more diffusely for rights, equality, justice, etc. This aspect was also addressed in cultural debates, as the national-popular was an important interpretative key of that time among intellectual groups, including student ones.

24 The invitation was made by Professor Maria Lisboa de Oliveira, advisor of the Dean, Professor Eduardo Osório Cisalpino, who chaired UFMG between 1974 and 1978. 


\section{SEWING MEMORIES}

Does memory only make sense after oblivion? Milton Натоum (2017, p. 234)

By trying to sew the (hi)stories of these four educators, we can say that their trajectories have some common aspects. As Halbwachs (2006) reminds us, the collective memory is produced by intercrossing shared experiences, many of them individual ones. Though there is a sharing of experiences that was common to women at the time, each one has its own perception of what happened, that is, a memory with singular characteristics. Therefore, subjectivity and individual experiences cannot or should not be overlooked when building memory and, consequently, producing history. What defines the ethical imperative of producing and maintaining memory is its potency to talk about times, spaces, and experiences that give sense to a common life. Thus, they affirm or undermine the existence of a political life. Therefore, the testimonies shown here, far from praising or refuting the value of the individual experience, represent a powerful indicator of a time when, to many people, educating was going beyond a technical and instrumental dimension and becoming a constitutive part of a political fight. The relevance of this type of register is in its power to understand that much of the current conservative and reactionary agenda was already fought against by the experiences of women who understood that education is more than a right, but a condition for a dignified life.

Among the four interviewees, we highlight the singularity of Efigênia Oliveira's experience. Her story is different from the others as her militancy did not start at a Teacher Training school or the university, but at the factory she used to work and in a rural school, experiences that would mark her professional and personal trajectory. A woman, a factory worker, a militant. Though not uncommon, it is an often-ignored case by the History of Education. But the four cases outlined retell the experiences of militant women that are rarely or never remembered by historiography, even several years after the publication of Michele Perrot's classic work warning about those who are excluded from History. Or the notion of gender, which has become one of the most researched categories in the Brazilian educational field. They were women, workers, militants, and prisoners in one of the darkest times in Brazilian history. Testimonies showing the authoritarianism that hit the country was faced with resistance, including a type of resistance that built a relationship between life and education.

The life stories shown here provide a glimpse into the intertwining of lives that have been built from a network of sociability, in which we find families, public and private schools, religious institutions (Catholic Church), organizations and political parties, universities, and agents working for the dictatorial regime. In those lives, we see aspects that are closer to or more distant from each other. Nevertheless, by analyzing the narratives, we found a converging point on these trajectories, which we consider to be a legacy to the history of women in Brazil. This point represents awareness and a continuous commitment to education and society, a fight for social justice, and a more solidary and humane society. This is a lot if we consider the moment 
of extreme individualism we are living. In this sense, youth militancy seems to have become a lasting mark of their experiences as teachers and educators who believed in the transformation of youth, and their roles in transforming society.

As in any ordinary life, their stories are permeated by obstinacy, challenges, fights, failures, and conquests. Certainly, there were memory lapses. However, in the case of these four women, the traumatic moments experienced in their youth did not erase their smiles, a serene but proud countenance that marks their aging. They are women who conquered their professional spaces, built their families, worked hard to guarantee the survival of democracy, and were full of vigor to restart their lives during redemocratization. Above all, these women help understand the past and update the memory of this country by sharing their valuable experiences as youngsters, educators, militants, and women.

Against all forms of erasing history and memory, we conclude by reminding readers that with no memory there is no justice. With no justice, there will never be a truly liberating education.

\section{REFERENCES}

ALBERTI, V.História oral: a experiência do CPDOC. Rio de Janeiro: FGV-CPDOC,1990. ARAÚJO, F. M. L. Dos espaços escolares e de militância política à sala de aula: percursos formativos e experienciais de educadoras brasileiras (1950-2000). 2018. Tesis (PhD in Education) - Programa de Pós-Graduação em Educação: Conhecimento e Inclusão Social, Faculdade de Educação, Universidade Federal de Minas Gerais, 2018. BENJAMIN, W. Magia e técnica, arte e política. São Paulo: Brasiliense, 1994.

BRAGHINI, K. Juventude e pensamento conservador no Brasil. São Paulo: EDUC; FAPESP, 2015.

BRAGHINI, K. A história dos estudantes “excedentes" nos anos 1960: a superlotação das universidades e um "torvelinho de situações improvisadas". Educar em Revista. Curitiba, n. 51, p. 123-144,Jan./Mar. 2014.https://doi.org/10.1590/S0104-40602014000100009 CARDOSO, I. A geração dos anos de 1960: o peso de uma herança. Tempo Social, São Paulo, v. 17, n. 2, p. 93-107,2005.https://doi.org/10.1590/S0103-20702005000200005 CASTRO, M. C. S. Entrevista realizada pelo autor. Belo Horizonte, May 3, 2018. CAVALCANTE, M. R. Entrevista realizada por Fátima Maria Leitão Araújo. Fortaleza, Nov. 13, 2015.

COLLING, A. M.A resistência da mulher à ditadura militar no Brasil. Rio de Janeiro: Record; Rosa dos Tempos, 1997.

COLLING, A. M. As mulheres e a Ditadura Militar no Brasil. In: CONGRESSO LUSO BRASILEIRO DE CIÊNCIAS SOCIAIS, 8., 2004, Coimbra. Anais [...]. Coimbra: Universidade de Coimbra, 2004.

COMISSÃO DA VERDADE EM MINAS GERAIS. Relatório final/Governo do Estado. Núcleo de História Oral da FAFICHE-UFMG. Belo Horizonte: COVEMG, 2017. v. 1-5. [Interview collection]. 
GARRIDO, F. A. Z. El trabajo docente durante la dictadura cívico-militar en Chile (1973-1990): una mirada desde las políticas públicas educacionales. História da Educação, Santa Maria, v. 24, 2020. https://doi.org/10.1590/2236-3459/92711 GERMANO, J. W. Estado militar e educação no Brasil: 1964-1985. São Paulo: Cortez, 1993.

HALBWACHS, M. A memória coletiva. São Paulo: Centauro, 2006.

HATOUM, M. A noite da espera. São Paulo: Companhia das Letras, 2017.

KAUFMANN, C. Dictadura y educación. Salamanca: FahrenHouse, 2017. t. I.

LENHARO, A. Sacralização da política. 2. ed. Campinas: Papirus, 1986.

MARTINS, M. C. Reflexos reformistas: o ensino das humanidades na ditadura militar brasileira e as formas duvidosas de esquecer. Educar em Revista, Curitiba, n. 51, Jan./ Mar. 2014. https://doi.org/10.1590/S0104-40602014000100004

MONTEIRO, H. S. Entrevista realizada por Fátima Maria Leitão Araújo. Fortaleza, Apr. 05, 2017.

MOTTA, R. P. As universidades e o regime militar. Rio de Janeiro: Zahar, 2014.

OLIVEIRA, E. M. Entrevista realizada por Fátima Maria Leitão Araújo. Cabo de Santo Agostinho, Pernambuco, Dec 04, 2017.

PINSKY, C. Estudos de gênero e história social. Revista Estudos Feministas, Florianópolis, v. 17, n. 1, p. 159-189, Apr. 2009. https://doi.org/10.1590/S0104026X2009000100009

POLLAK, M. Memória e identidade social. Estudos Históricos, Rio de Janeiro, v. 5, n. 10, p. 200-212, 1992. Available at: http://www.pgedf.ufpr.br/memoria\%20e\%20 identidadesocial\%20A\%20capraro\%202.pdf. Acsessed on: Dec. 01, 2021.

POLLAK, M. Memória, esquecimento e silêncio. Estudos Históricos, Rio de Janeiro, v. 2, n. 3, p. 3-15, 1989. Available at: https://bibliotecadigital.fgv.br/ojs/index.php/reh/ article/view/2278. Acsessed on: Dec. 01, 2021.

REIS FILHO, D. A; MORAES, P. 1968: a paixão de uma utopia. 2. ed. Rio de Janeiro: Fundação Getulio Vargas, 1998. v. 1.

REIS FILHO, D. A.; MOTA, R. P. S. Ditadura e democracia no Brasil: 50 anos depois - do golpe de 1964 à Constituição de 1988. Rio de Janeiro: Zahar, 2014.

REIS FILHO, D. A.; MOTA, R. P. S. 1968: O curto ano de todos os desejos. Tempo Social, São Paulo, n. 10, p. 25-35, Oct. 1998.

ROSA, S. O. Mulheres: ditadura e memórias - Não imagino que precise ser triste para ser militante. São Paulo: Intermeos; FAPESP, 2013.

TABORDA DE OLIVEIRA, M. A. La experiencia de una profesora escolar como posibilidad de pensar y hacer de la escuela un lugar de cultura. Trayectoria formativa de buenas prácticas educativas. Educacion Fisica y Deporte, v. 33, p. 125-161, 2014. http://doi.org/10.17533/udea.efyd.v33n2a06

TABORDA DE OLIVEIRA, M. A. Educação Física escolar e civil-ditadura militar no Brasil (1968-1984): entre a adesão e a resistência e outros estudos. Curitiba: Editora da UFPR, 2018. 
THOMPSON, E. P. A miséria da teoria ou um planetário de erro: uma crítica ao pensamento de Althusser. Rio de Janeiro: Zahar, 1981.

THOMPSON, P. A voz do passado história oral. Rio de Janeiro: Paz e Terra, 1992.

WILLIAMS, R. La larga revolución. Buenos Aires: Nueva Visión, 2003.

\section{ABOUT THE AUTHORS}

Fátima Maria Leitão Araújo has a doctorate in Brazilian Education from the Universidade Federal do Ceará (UFC). She is a professor at the Universidade Estadual do Ceará (UECE).

E-mail: fatima.leitao@uece.br

Marcus Aurélio Taborda de Oliveira has a doctorate in History and Philosophy of Education from the Pontifícia Universidade Católica de São Paulo (PUC-SP). He is a professor at the Universidade Federal de Minas Gerais (UFMG).

E-mail: marcustaborda@uol.com.br

Conflicts of interest: The authors declare they don't have any commercial or associative interest that represents conflict of interests in relation to the manuscript.

Funding: Conselho Nacional de Desenvolvimento Científico e Tecnológico (CNPq), with the scholarship modality of productivity (n. 307361/2018-7); Programa de Excelência Acadêmica da Coordenação de Aperfeiçoamento de Pessoal de Nível Superior (PROEX/ CAPES).

Authors' contribution: Writing - First Writing, Writing - Reviewing and Editing, Methodology: Leitão, F.; Taborda de Oliveira, M. Formal Analysis, Data Curatorship: Leitão, F. Conceptualization, Research: Taborda de Oliveira, M.

Received on August 24, 2020 Approved on April 9, 2021 